\title{
STUDENT WORKSHEET ORIENTED ON PROJECT BASED LEARNING TO TRAIN STUDENT CREATIVE THINKING SKILLS ON ACID-BASE MATERIAL
}

\author{
Balqis Luthfiyyatus Zahro and Mitarlis* \\ Chemistry Department Mathematics and Natural Science Faculty Universitas Negeri Surabaya \\ e-mail: mitarlis@unesa.ac.id ${ }^{*}$
}

\begin{abstract}
The aim of this research is to determine the feasibility of student worksheet oriented on project based learning (PjBL) to train students' creative thinking skills on acid-base material. The research method referred to the 4D development design that consisting of 4 stages including: (1) define, (2) design, (3) development, and (4) dissemination. This research was limited to development stage. The limited trial was treated to 12 students of eleventh grade of a State Senior High School. Feasibility of worksheet was reviewed from the content validity and the construct validity (aspect of language, presentation, and graph) through validation results of experts, practicality through student activity observation and student response, and effectiveness through creative thinking skills test. Creative thinking skills included four aspects: fluency, flexibility, elaboration, and originality. The data analysis used qualitative and quantitative descriptive analysis methods. The results showed that the developed worksheet was valid in terms of content validity $(84.44 \%)$ and construct validity $(83.63 \%)$. Practicality in terms of relevant student activities observation and student responses got percentage of $92.74 \%$ and $93.66 \%$ in very practical category. The effectiveness of creative thinking skills training in terms of the $\mathrm{N}$-gain score had a percentage of 0.60 in enough category.
\end{abstract}

Key words: worksheet, project based learning, creative thinking skills.

\section{INTRODUCTION}

Based on the Minister of Education and Culture Regulation number 22 the year 2016 about the standard of basic and secondary education has been explained that one of the learning principles is learning that emphasizes the single answer towards learning to learn with multidimensional correct answer [1]. Based on this principle of learning, a very important competency for training is creative thinking skills.

Creative thinking is the ability to provide a variety of answers based on information provided with an emphasis on diversity of numbers and suitability [2]. If the students' creative thinking skills are growing, the more likely students are to find various alternative answers. There are four components of creative thinking skills, including fluency, flexibility, originality and elaboration [3]. Fluency is the ability to generate a lot of ideas quickly, flexibility is the ability to generate ideas and answers that are reviewed from various points of view, originality is the ability to trigger original ideas, and elaboration is the ability to complete or detail of an idea.

Based on pre-research results, students stated that it would be easier to understand learning material if it was related to phenomena in the environment (96.1\%). However, students also expressed infrequently (27.5\%) and never $(41.2 \%)$ gave ideas to a phenomena related to the chemistry learning materials. This indicate that learning activities in the classroom was still lacking in training the creative thinking skills of students. Therefore, a learning model is needed to train students' creative thinking skills using relevant phenomena to material in learning process, such as project based learning $(\mathrm{PjBL})$.

Students in PjBL face problems in real life that can lead to permanent knowledge acquisition [4]. Through relevant phenomena in PjBL, students can get an idea of material concepts and its implementation, so students can independently find and apply concepts that have been acquired (originality) to be used in obtaining various ideas (fluency) related to material that is reviewed from 
various affecting aspects (flexibility) to be more detailed (elaboration).

Project based learning model can be interpreted as a learning model that involves concentration of meaningful question and problem, problem solving, decision making, various sources search process, giving students the opportunity to work collaboratively, and closing with a real product presentation [5]. In focusing on question and problem, students are trained to find problem solving and perform the search process from various sources, so students are stimulus to think outside the habit and try to involve new ways of thinking to fulfill aspects of fluency, flexibility, elaboration and originality. In addition, the learning process that is carried out can be centered on students. The modified of stages activities in PjBL involve three steps are introduction, main activity and closing. The main activity divided into six phases, including: (1) start with essential question (design project), (2) plan of procedure for the project, (3) create a schedule, (4) action the project with the facility and monitoring, (5) reporting and presenting the result of the project, and (6) evaluate process and outcome of the project [6] adapted from [7].

Chemistry in learning is a subject that combines memorization systems, understanding concepts, and calculations. Based on pre-research results on 54 students of a State Senior High School about chemistry studies, $60.8 \%$ of students expressed interest in chemistry subjects. However, there was material that less interesting according to students and difficult to understand, although it had a very relate in its application in daily life, i.e. acidbase material. It was based on results of the questionnaire which $31.4 \%$ of students who expressed interest in acid-base material and $23.5 \%$ of students expressed understanding.

Basic competence based on Minister of Education and Culture Regulation number 37 the year 2018 on acid-base material, students are expected to explain the concept of acid-base and its strength and equilibrium in solution (basic competence 3.10), and analyze the route of $\mathrm{pH}$ changes several indicators that extracted from natural materials through experiments (basic competence 4.10) [8]. Based on the basic competencies, acid-base material is a material that requires students to relate concepts with its application in daily life, proven through laboratory experiments.

The impact of education to create independent and creative thinking skills should be integrated into the education system as a tool to enhance the educational process; facilitate better learning, skill, and ability; and to stimulate educational motivation [9]. Problems and challenges in project activities are becoming an effort to develop innovative and creative strengths [10]. The students' creative thinking skills, using PjBL model, are better than students using conventional learning models [11]. Therefore, $\mathrm{PjBL}$ as a learning can provide an actual experience that needed to train students' creative thinking skills in acid-base material.

In learning process is related to learning resources. Learning resources is information that presented and stored in various forms of media, which can help students in learning. Learning resources will be meaningful for students and teachers when it is organized through a plan which allows someone to use it as a learning resource [12]. Based on pre-research results, students used students' worksheet $(78.4 \%)$ as a source of learning and wanted a worksheet that can relate learning materials with the phenomena in environment through experimental activities (51\%). In addition, students wanted chemistry learning by providing experience to arrange experimental activities according to students' ideas (88\%) and expressed approval if there is a worksheet of $\mathrm{PjBL}$ oriented to help understanding $(92.2 \%)$.

Based on the explanation above, it is necessary to develop a worksheet as a learning resource for students to improve the quality of chemistry learning. The research aim was to determine feasibility of student worksheet oriented on $\mathrm{PjBL}$ to train students' creative thinking skills on acid-base material in terms of validity, practicality, and effectiveness.

\section{METHOD}


This research was a development research about the developed worksheet of PjBL to train students' creative thinking skills on acid-base material. Research method referred to the development model of 4D that consists of 4 stages, including: (1) define, (2) design, (3) development, and (4) dissemination [13]. This research was limited to development stage. Procedures of this research by using observation, questionnaire, and test.

The questionnaire was used as a data collection method to determine feasibility of developed worksheet. Questionnaire was given to several respondents, including chemistry lecturers, chemistry teacher, and students. Questionnaires for chemistry lecturers and chemistry teacher aimed to get review and media validation. Questionnaire for students aimed to know students' response to developed worksheet in limited trials. The number of students that used in the limited trial was to 12 students of XI MIPA a State Senior High School, which were selected heterogeneous based on their academic abilities.

According to the National Standards Agency of Education (BSNP) about the instrument of assessment textbook lessons of 2014, there are four aspects that should be raised in developed worksheet including the aspect of content, language, presentation and graph [14]. The instruments used in the research included review sheet, validation sheet, student response questionnaire, and test of creative thinking skills sheet.

On the review sheet, data was analyzed using qualitative descriptive method. Qualitative descriptive method was used to analyze data by describing data that had been collected. The validation sheet was analyzed using quantitative descriptive method of representation and scoring exposure in percentages. The percentage result was derived from the calculation of the Likert scale as presented on Table 1.

Table 1. Likert Scale

\begin{tabular}{cc}
\hline Category & Score \\
\hline Very good & 5 \\
Good & 4 \\
Medium & 3
\end{tabular}

\begin{tabular}{cc} 
Bad & 2 \\
Very bad & 1 \\
\hline
\end{tabular}

The calculation data of Likert scale calculate in percentage as presented on formula (1):

$$
\mathrm{K}=\frac{F}{N \times I \times R} \times 100 \%
$$

$\mathrm{K}=$ percentage of assessment

$\mathrm{F} \quad=$ number of respondents' answer

$\mathrm{N} \quad=$ highest score for each aspect

I = number of aspect

$\mathrm{R}=$ number of validators

The worksheet is stated to be valid if it has a minimum percentage of $61 \%$, using the score interpretation criteria as presented on Table 2 .

Table 2. Criteria for Interpretation of Validity Percentage

\begin{tabular}{cc}
\hline Percentage (\%) & Category \\
\hline $0-20$ & Not Valid \\
$21-40$ & Less Valid \\
$41-60$ & Valid Enough \\
$61-80$ & Valid \\
$81-100$ & Very Valid \\
\hline
\end{tabular}

The Student Response questionnaire analysis was analyzed by quantitative descriptive method through evaluation of developed worksheet. The percentage of student questionnaire data was calculated based on the Guttman score scale.

Table 3. Guttman Scale

\begin{tabular}{cc}
\hline Assessment & Score \\
\hline Yes & 1 \\
No & 0 \\
\hline
\end{tabular}

The data is calculated to get the percentage of student response result as presented on formula (2):

$$
\mathrm{P}=(\mathrm{F} / \mathrm{N}) \times 100 \%
$$

$\mathrm{P} \quad=$ percentage of respondent answer

$\mathrm{F} \quad=$ amount of yes answer

$\mathrm{N}=$ amount of respondent

The percentage result that obtained can be interpreted as presented criteria on Table 4.

Table 4. Criteria for Interpretation of Practical Percentage

Percentage (\%) Category




\begin{tabular}{cc}
\hline $0-20$ & Not Practical \\
$21-40$ & Less Practical \\
$41-60$ & Practical Enough \\
$61-80$ & Practical \\
$81-100$ & Very Practical \\
\hline
\end{tabular}

Worksheet based on project based learning to train creative thinking skills is stated to be practical if obtain a percentage of $\geq 61 \%$ in practical criteria and very practical.

\section{Final Test}

The analysis of the test results was used to determine creative thinking skills improvement of students in acid-base material. Tests of students' creative thinking skills were given before (pretest) and after (posttest) using worksheet based on project that was analyzed using the equation of gain index according to the following formula (3):

$$
\begin{aligned}
& N-\text { gain }=\frac{S_{\text {posttest }}-S_{\text {pretest }}}{S_{\text {max }}-S_{\text {pretest }}} \\
\mathrm{S}_{\text {pretest }} & =\text { pretest score } \\
\mathrm{S}_{\text {posttest }} & =\text { posttest score } \\
\mathrm{S}_{\max } & =\text { maximum score }
\end{aligned}
$$

The obtained gain index results can be interpreted as presented category on Table 5 .

Tabel 5. Category for $N$-gain Score

\begin{tabular}{cc}
\hline Score & Category \\
\hline $\mathrm{g} \geq 0,7$ & High \\
$0,7>\mathrm{g} \geq 0,3$ & Enough \\
$\mathrm{g}<0,3$ & Low \\
\hline
\end{tabular}

Based on the analysis results, students' creative thinking skills are considered increasing when $\mathrm{N}$-gain score reaches $\geq 0.3$ (enough category).

\section{RESULT AND DISCUSSION}

The developed worksheet is a worksheet that is compiled oriented on the stages of a project based learning model and is used to train students' creative thinking skills in each stage. The worksheet is developed according to the procedure of $4 \mathrm{D}$ development model, the result as below.

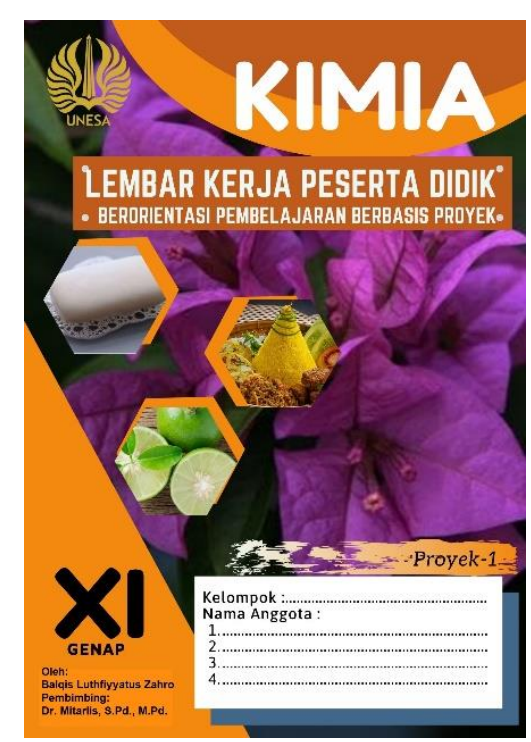

Figure 1. Cover of Developed Worksheet

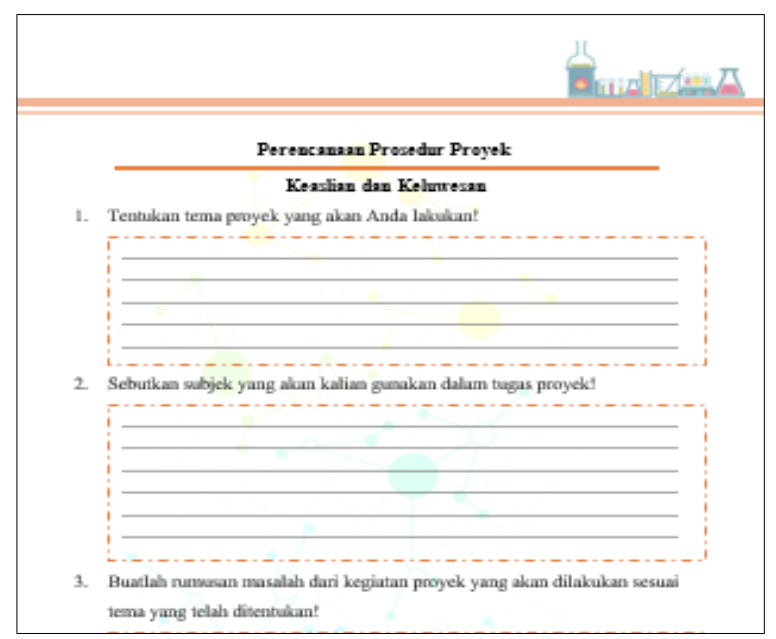

Figure 2. Second Phase of PjBL (Plan of Procedure for The Project)

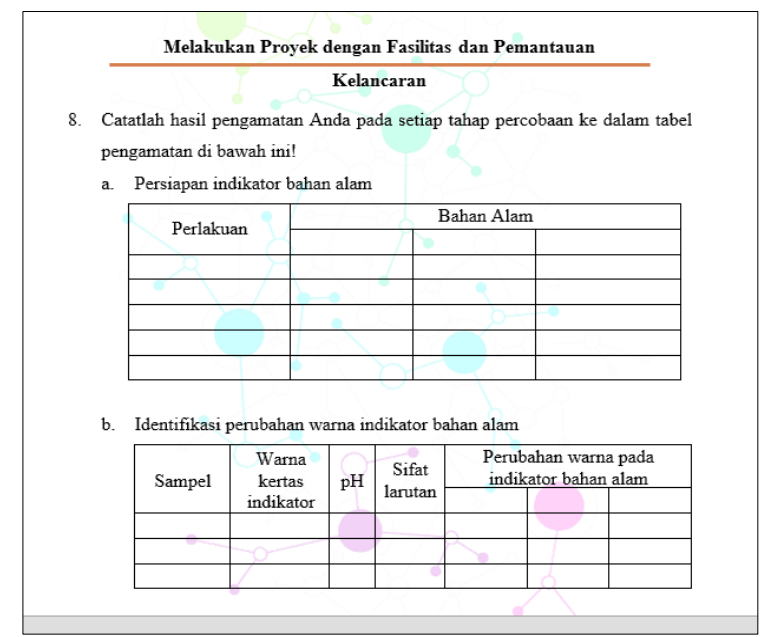

Figure 3. Fourth Phase of $\mathrm{PjBL}$ (Action The Project with The Facility and Monitoring) 


\section{Validity}

Media validation was used to know the truth and accuracy of the developed worksheet. The results of validation were reviewed from chemistry lecturers and chemistry teacher assessments, which analyzed using quantitative descriptive methods. Component of validation consisted of content and construct validity. The content validity results are presented in Figure 1 below:

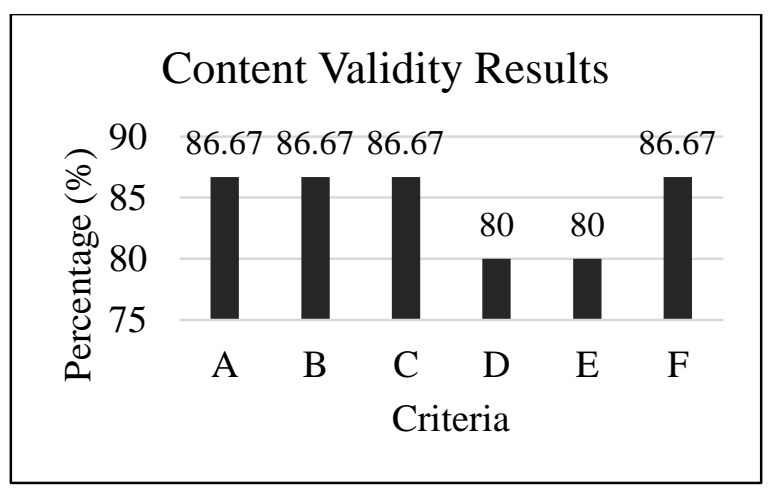

Figure 4. Diagram of Content Validity Results of Developed Worksheet

Assessment of feasibility aspect of content validity based on Diagram 1 consists of six criteria, including:

A : suitability of basic competencies and indicators to be achieved with the 2013 Curriculum (86,67\%),

B : suitability of material with learning objectives $(86,67 \%)$,

C : suitability of phenomena that presented $(86,67 \%)$,

D : suitability of PjBL model (80\%),

E : suitability of creative thinking skills (80\%),

F : developed worksheet ability in improving students' scientific attitudes $(86,67 \%)$.

Assessment criteria (D) regarding the suitability of a PjBL model consists six stages, including: start with essential question (design project), plan of procedure for the project, create a schedule, action the project with the facility and monitoring, reporting and presenting the result of the project, and evaluate process and outcome of the project reaches $80 \%$ in valid category. Assessment criteria (E) regarding the suitability of creative thinking skills reaches $80 \%$ in valid category consists four skill components, including fluency, flexibility, detail, and originality. Overall, average percentage value of content validity is $84.44 \%$ with a Likert scale interpretation classified as very valid category [15].

The construct validity consists of three aspects, including language, presentation, and graph aspects. The construct validity results are presented in Figure 2 below:

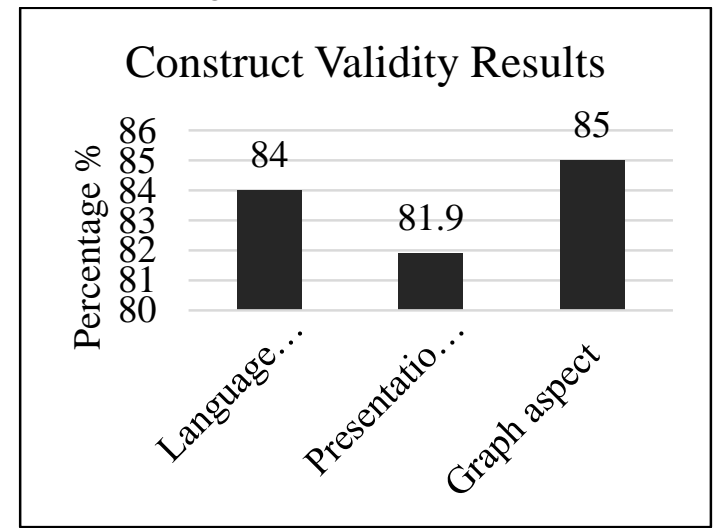

Figure 5. Diagram of Construct Validity Results of Developed Worksheet

The language aspect is used of appropriate grammar, so expected information can be conveyed. Assessment of language aspects is based on the following five criteria, including: use of terms that are in accordance with KBBI or Indonesia dictionary (80\%), use of Indonesian that is good and correct (80\%), coherence and relevance of each sentence so it has full meaning (93.33\%), use of right terms, and symbols (86.67\%), and use of language that is effective and efficient (80\%). Based on these categories, the language aspect reaches a percentage of $84 \%$.

The presentation aspect is an procedure assessment for delivering information in developed worksheet, which consists seven criteria, including: clarity of objectives presented (86.67\%), material systematic presentation (86.67\%), presentation of material in interactive and participative $(80 \%)$, presentation of material that encourages students to be more active (80\%), suitability of image presentation with material $(80 \%)$, presentation of references in figures $(80 \%)$, and presentation of interesting and fun worksheet $(80 \%)$. Presentation aspect obtains percentage of $81.90 \%$. 
The graph aspect has four criteria of assessment, including: use of covers that present contents of worksheet (93.33\%); use of appropriate font and text size (86.67\%); compatibility of text and image layouts (80\%); and use of appropriate illustration, graphic, and image (80\%). Graph aspect obtains percentage of $85 \%$. Overall construct validity has an average percentage of $83.67 \%$ with a Likert scale interpretation classified as very valid category [15].

\section{Practicality}

Practicality is used to assess the easiness of media application. Practicality of worksheet can be known through results of student activities observations when they using developed worksheet and student response questionnaire. Observation of student activities is carried out by three observers during the learning process. The data from observation of student activities can be seen from the training process for creative thinking skills that is adjusted based on PjBL model stages.

Creative thinking skills is a thinking ability that contains aspects of cognitive and metacognitive skills, such as identifying problems, arranging questions, and generating many different ideas and new products [17]. Students' creative thinking skills were trained through worksheet, which is developed based on PjBL model. Projectbased learning has six main activities [6] adapted from [7], where the components of creative thinking skills are trained at the appropriate stage of activity. At stage I, start with essential question (design project), students were given chance to determine the tasks that will be done according to ideas related to the theme (originality) to stimulate student motivation as a condition for integrating creative thinking skills in the education system [9]. Stage II or plan of procedure for the project and stage III or create a schedule were expected to train students' skills in generating ideas and answers that vary from various points of view. Stage IV, action the project with the facility and monitoring, could be used to observe students' skills to give ideas quickly related to project completion and accuracy on schedule that had been arranged (fluency). Stage V, reporting and presenting the result of the project, could be used to train students' skills in developing or detailing results of practicum through analyzing activities in accordance with relevant theories (detail) which were then evaluated to obtain feedback from projects that had been done in stage VI or evaluated process and outcome of the project.

Observers were observing relevant student activities by ticking the "Yes" column and giving a score of 1 then analyzed using the Guttman score scale during the research process [15]. In research process, PjBL model's stage were carried out at three meetings sequentially. The first research meeting was carried out at stage I to stage III which focused on project planning, project completion was occurred at IV stage in second meeting, and the third meeting was continued at stage $\mathrm{V}$ to stage VI which focused on activities of delivering results and evaluating processes in project activities. The percentage of relevant activities in the first, second, and third stages are $95.83 \% ; 92.50 \% ; 89.58 \%$. The average percentage at three meetings is $92.74 \%$.

The students' response from using developed worksheet was accommodated in response questionnaire sheet then analyzed using quantitative descriptive methods to determine the practicality of the developed worksheet. Practicality has content aspect, language aspect, presentation aspect, and graph aspect [14]. The practicality analysis results of each assessed aspects are presented in the following figure:

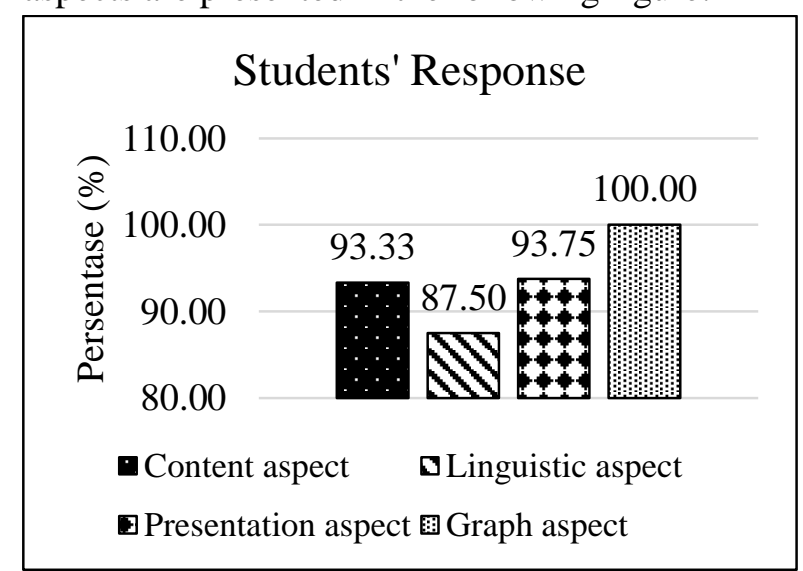

Figure 6. Diagram of Students' Response Analysis Result

The content aspect, related to material content in developed worksheet, consists of five criteria, including: clarity of the material provided to give ease of understanding (100\%), suitability of 
the questions that are given to the characteristics of creative thinking skills $(83.33 \%)$, existence of project activities is in accordance with the material $(100 \%)$, ability of developed worksheet to improve scientific attitudes (91.67\%), and availability of a chance to give ideas $(91.67 \%)$. Overall, the content aspect has a students' response percentage of 93.33\%.

The language aspect is assessed based on two criteria, including: use of terms that are easy to understand (83.33\%) and use of short and clear language (91.67\%). The Language aspect has a response percentage of $87.50 \%$.

The presentation aspect consists of four criteria, including: use of questions that are easy to understand $(83.33 \%)$, presentation of material systematically (100\%), presentation of developed worksheet attractively (100\%), and presentation of developed worksheet that can arouse motivation and curiosity (91.67\%). Overall, the presentation aspect has a response percentage of $93.75 \%$.

The graph aspect obtains a response percentage of $100 \%$ on all criteria, including: use of attractive covers, use of types and sizes of text that make it easy to use, use of illustration or image that can help to understand the concepts, and layout of appropriate text and images. Based on these four aspects, the practicality of developed worksheet has a response percentage of $93.66 \%$ in very practical.

\section{Effectiveness}

The effectiveness of using developed worksheet to train creative thinking skills could be observed through test results. Tests made consisted of two phases, namely pretests and posttest. Pretest was given to students before using developed worksheet, while Posttest was given after receiving developed worksheet. Creative thinking skills improvement was characterized by improvement results from pretests to posttest through the process of analysis of the $\mathrm{N}$-gain [16]. Here are the results of the influence analysis of developed worksheet on each component of the students' creative thinking skills:

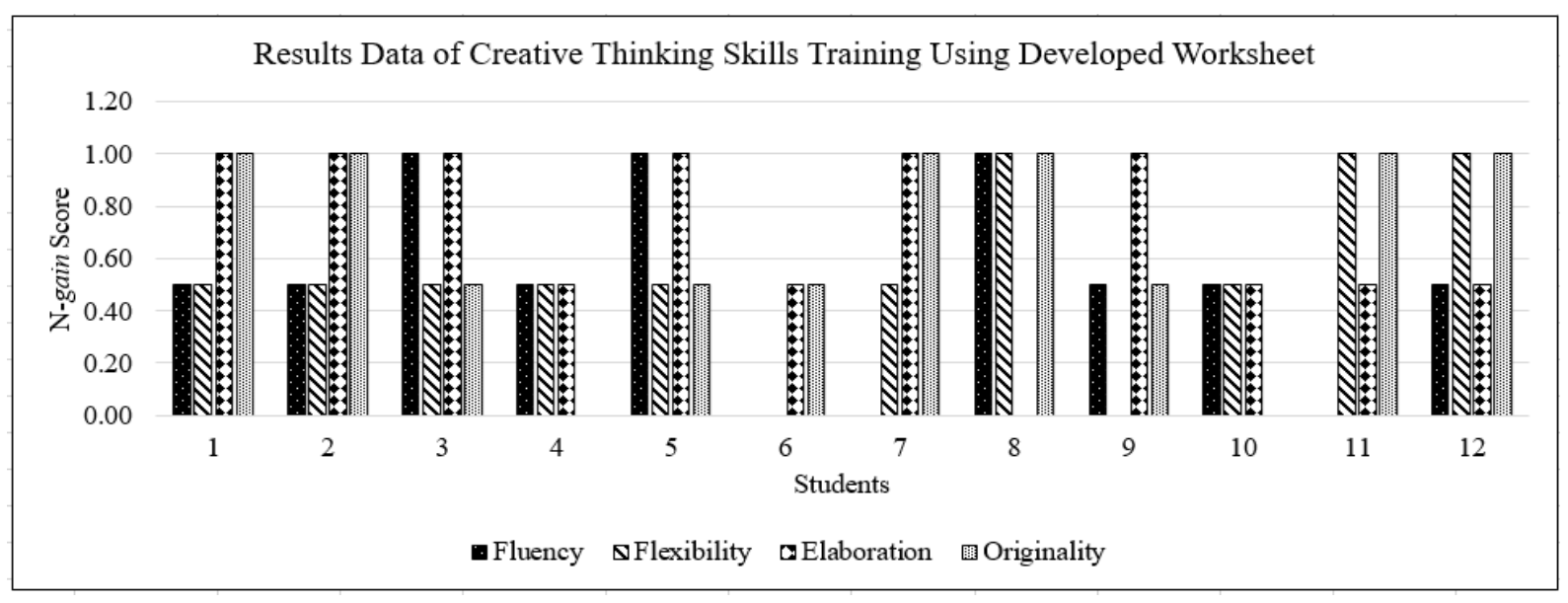

Figure 7. Results Data of Students Creative Thinking Skills Training Using Developed Worksheet

Based on Figure 4, the results of students creative thinking skills training is based on four aspects, including fluency, flexibility, elaboration, and originality [2] and [3]. Student is analyzed an increase in each aspect of creative thinking skills using N-gain score. There are some students who gain an increase in creative thinking skills in two or three aspects, while some students gain an increase in all aspects.
The following figure is an example of students work result on developed worksheet:

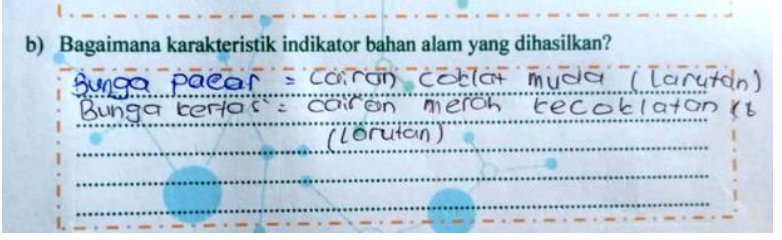

Figure 8. Students Work Result in Elaboration Aspect of Less Creative Category 


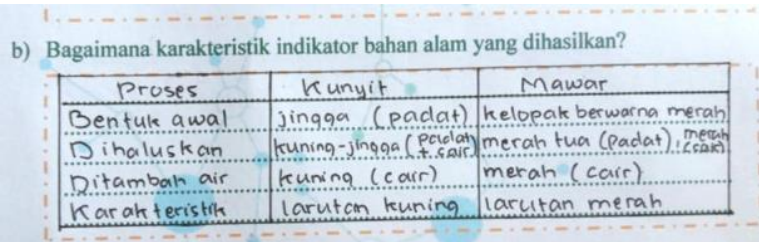

Figure 9. Students Work Result in Elaboration Aspect of Creative Category

Fluency is a creative thinking skill in generating many ideas [3]. In research, testing of fluency skills was done by giving phenomena about the types of natural material indicator in surrounding environment that stimulus students to provide many alternative answers. Assessment of fluency was based on the number of answer. In the pretest, most students only answered 2-3 kinds of natural material indicator in surrounding environment and gain improvement in the posttest by answering 3-4 kinds of natural material indicator, while 3 children were able to answer up to 7 kinds of natural material indicator. This causes the overall fluency aspect to get an N-gain score of 0.50 in enough category according to the score criteria of Hake [16] even though there are 75\% of students who gain improvement in ability of fluency aspect.

Flexibility is a creative thinking skill in generating ideas that are reviewed from different categories that affect [3]. Flexibility aspect was trained using phenomena that stimulate students to provide some ideas in problem solving. Problems in project activities are becoming an effort to develop innovative and creative strengths [10]. Students when asked to give some ideas about the practical procedure for making natural material indicators, generally answer with a procedure for making natural material indicators without mentioning how to test for color changes in acidic and alkaline conditions at the pretest. However, there was improvement ability during the posttest where students were able to answer several practical procedures for making natural material indicators until test for color changes in acidic and alkaline situations even though there were some inaccurate work steps. This causes the flexibility aspect obtains an $\mathrm{N}$-gain score of 0.54 in enough category even though there are $83 \%$ of students who have increased their ability in flexibility aspect.

Elaboration is a creative thinking skill in detailing product [3]. Elaboration aspect were trained by giving phenomena of practicum results regarding acid-base properties testing of some materials in surrounding environment, students conveyed the details of practicum results through the analysis and concluded it. As many as $92 \%$ of students gain improvement skills, so overall elaboration aspect obtain an $\mathrm{N}$-gain score of 0.71 in high category.

Originality was trained to students by giving a chance that could be used to accommodate ideas of students in accordance with the phenomena given, such as through arrangement of themes, designing project activities, and organizing a schedule of project completion. In originality aspect, $83 \%$ of students gain improving skills, so overall gain an $\mathrm{N}$-gain score of 0.67 in enough category.

Based on the four aspects of creative thinking skills above, high category improvement is in elaboration due to obtaining an N-gain score $>0.7$. Enough category improvement is in fluency, flexibility, and originality due to obtaining an Ngain score $>0.3$. Overall, the four aspects of creative thinking skills gain enough category improvement with an $\mathrm{N}$-gain score of 0.60 [16]. This can be concluded if developed worksheet is effective to improve creative thinking skills of students.

\section{CLOSURE}

\section{Conclusion}

Based on the data analysis and discussion, it can be concluded that the developed worksheet is feasible for use with the following details:

1. Validity of the developed worksheet includes content validity and construct validity which is stated valid and feasible by obtaining a percentage of $84.44 \%$ and $83.63 \%$ respectively in very valid categories.

2. Practicality of developed worksheet in terms of observation of student activities obtained a percentage of $92.74 \%$ on relevant activities 
and response of students was $93.66 \%$ in very practical category.

3. Effectiveness of developed worksheet in terms of an average $\mathrm{N}$-gain score of 0.60 in enough category.

\section{Suggestion}

Based on the research's results that has been done, the following suggestions are presented:

1. Limited trials are carried out for students who have not yet received the concept to be taught, but already have requirements to receive acidbase indicator material, so it is appropriate the project-based learning model.

2. Focusing research on one aspect of creative thinking skills, so research can be carried out more deeply and direction.

\section{REFFERENCES}

1. Kemendikbud. 2016. Peraturan Menteri Pendidikan dan Kebudayaan Nomor 22 Tahun 2016 tentang Standar Proses Pendidikan Dasar dan Menengah. Jakarta: Kemendikbud.

2. Munandar, Utami. 2009. Pengembangan Kreativitas Anak Berbakat. Jakarta: PT Rineka Cipta.

3. Almeida, Leandro S., et al. 2008. Torrance Test of Creative Thinking: The Question of Its Construct Validity. Journal of Thinking Skills and Creativity, vol. 3, issue 1, pp. 53-58.

4. Rohmawati, Ria Indri. 2018. Pengembangan Lembar Kegiatan Siswa (LKS) Berbasis Proyek pada Materi Struktur dan Fungsi Jaringan Tumbuhan untuk Melatihkan Keterampilan Berpikir Kreatif. Skripsi. Surabaya: Program Studi Pendidikan Biologi, Fakultas Matematika dan Ilmu Pengetahuan Alam Universitas Negeri Surabaya.

5. Hosnan, M. 2014. Pendekatan Saintifik dan Kontekstual dalam Pembelajaran Abab 21. Bogor: Ghalia Indonesia.

6. Mitarlis, Bertha Yonata dan Rusly Hidayah. 2017. Implementation of Science Character Value with Green Chemistry Insight Integrated on Basic Chemistry Course by Using Project Based Learning. American Scientific Publishers, 23, 11943-11947. Available: www.ingentaconnect.com.
7. The George Lucas Educational Foundation, Instructional Module Project Based Learning 2005. Available online: http//www.edutopia. org.modules/PBL/whatpbl.php.2005

8. Kemendikbud. 2018. Permendikbud No. 37 Tahun 2018 tentang Perubahan Atas Peraturan Menteri Pendidikan Dan Kebudayaan Nomor 24 Tahun 2016 Tentang Kompetensi Inti Dan Kompetensi Dasar Pelajaran Pada Kurikulum 2013 Pada Pendidikan Dasar Dan Pendidikan Menengah. Jakarta: Kemendikbud.

9. Isabekov, A., \& Gulzat Sadyrova. 2018. Project-Based Learning to Develop Creative Abilities in Students. Journal of Technical and Vocational Education and Training, vol. 28, no. 4, pp. 43-49, [online]. Available: link.springer.com.

10.Sharipova, N., \& Matthias Wesseler. 2018. Strengthening the Innovative Potential of Project Based Learning for TVET. Journal of Technical and Vocational Education and Training, vol. 28, no. 3, pp. 27-42, [online]. Available: link.springer.com.

11.Tamba, P., Motlan, \& Betty M. Turnip. 2017. The Effect of Project Based Learning Model for Students Creative Thinking Skills and Problem Solving. Journal of Research \& Method in Education, vol. 7, Issue 5 Ver. II, pp. 67-70, [online]. Available: www.iosjournals.org.

12.Depdiknas. 2008. Panduan Pengembangan Bahan Ajar. Jakarta: Direktorat Pembinaan Sekolah Menengah Atas.

13.Ibrahim, M., dan Wahyusukartiningsih. 2014. Model Pembelajaran Inovatif Melalui Pemaknaan. Surabaya: Unesa University Press.

14.BSNP. 2014. Instrumen Penilaian Buku Teks Pelajaran. Jakarta: Kemendikbud.

15.Riduwan. 2016. Skala Pengukuran VariabelVariabel Penelitian. Bandung: Alfabeta.

16.Hake, Richard Robb. 1998. Interactive Engagement Versus Traditional Method: A Six Thousand Student Survey of Mechanics Data for Introduction Physics Courses. American Journal Physics, 66 (1), 64-67.

17.Moma, L. 2015. Pengembangan Instrumen Kemampuan Berpikir Kreatif Matematis Untuk Siswa Smp. Jurnal Matematika dan Pendidikan Matematika, vol. 4, no. 1, pp. 27-38. Available: ejournal.unkhair.ac.id. 
